ЛАПКО А. О., канд. техн. наук, доцент, КАМЕНСВ О. Ю., канд. техн. наук, доцент, САГАЙДАЧНИЙ В. Г., аспірант

(Український державний університет залізничного транспорту), КОЦЮБА Т. А., викладач (Харківський коледж транспортних технологій)

\title{
Експлуатаційні показники роботи пристроїв залізничної автоматики
}

Для підтримки справності пристроїв залізничної автоматики (3А) на сьогодні використовується плановопрофілактична стратегія технічного обслуговування (ТО) при організачії самої системи ТО. Недоліком названої стратегії є значна залежність імовірності безвідмовної роботи пристроїв від якості та своєчасності виконання технологічних процесів ТО. 3 метою аналізу впливу прочесу ТО на імовірність безвідмовної роботи пристроїв 3А, і відповідно впливу на параметри перевізного процесу, опрацьовано статистичні дані щзодо відмов пристроїв ЗА. У результаті було отримано кореляційну залежність між кількістю відмов та кількістю затримок поїздів. При иъьому було сформовано розрахунково-логічну схему безвідмовності як функцію декількох складових ТО в ролі аргументів.

Ключові слова: технічне обслуговування, відмова, кореляційний зв'язок, технічний контроль, діагностика.

\begin{abstract}
Вступ
Системи ЗА являють собою складний комплекс електротехнічних та механічних пристроїв, між якими $\epsilon$ чіткі функціонально-логічні залежності, зокрема і 3 убезпечення руху поїздів. Технологія, методи та стратегія технічного обслуговування систем ЗА останнім часом майже не зазнали змін. Про це свідчить кількість та характер відмов не тільки на мережі залізниць України, а й в інших країнах пострадянського простору, де експлуатуються аналогічні системи [1-3]. Не в останню чергу відсутність суттєвих змін у ТО пов'язана з низькою інтенсивністю впровадження нових систем ЗА. Так, на сьогодні сучасним мікропроцесорним устаткуванням обладнано $3 \%$ станційних систем (758 стрілок) та $1 \%$ перегінних систем (157,6 км). Поліпшити ситуацію можна шляхом упровадження більш досконалих сучасних систем і пристроїв та відповідно зміною стратегії технічного обслуговування пристроїв 3А, за умови введення засобів та методів технічної діагностики 3 прогнозуванням технічного стану об'єктів. Для цього необхідно дослідити негативні явища, що призводять до появи відмов.
\end{abstract}

\begin{abstract}
Аналіз останніх досліджень і публікацій
У роботі [2] розглянуто проблемне питання, пов'язане із відсутністю статистики експлуатації сучасних технічних засобів ЗА поряд із традиційними. Для часткового вирішення проблеми запропоновано використання методів мікростатистики, зокрема розподілу Стьюдента, методів максимальної правдоподібності та нерівноточних спостережень. Проте запропоновані підходи не враховують зв'язок відмов пристроїв ЗА із експлуатаційними показниками роботи залізниці.

Робота [3] пропонує використання адаптивних алгоритмів для людино-машинної діагностики засобів 3А в процесі ТО. Однак недоліком запропонованих підходів $\epsilon$ відсутність критерію пріоритетності технічного діагностування пристроїв ЗА відповідно до наявної статистики відмов за функціональними групами. Такий стан речей зобов'язує розробників методів та засобів ТО встановити необхідні кореляційні залежності між відсотком відмов, типом та функціональним призначенням відповідних
\end{abstract} засобів ЗА. 


\section{(C) А. О. Лапко, О. Ю. Каменєв, В. Г. Сагайдачний, Т. А. Коцюба, 2019}

У роботі [4] наведено дані про те, що на процеси ТО пристроїв 3А негативно впливає обслуговуючий персонал на рівні виконання робіт з ТО, що можна віднести до суб'єктивних явищ. Попередній аналіз існуючих відмов дав змогу виявити таку особливість, що при зменшенні загальної кількості відмов кількість відмов, що спричинили затримку поїздів, майже не змінилася. Не змінилася і відсоткова пропорційність як відносно пристроїв ЗА, що мали відмови, так і причин відмов. Такий стан речей вказує на не досить задовільні процеси в ТО і потребує внесення суттєвих змін у технологію та організацію ТО 3 урахуванням кількісного зменшення кваліфікованого людського pecyрсу (сучасний термін менеджменту - human resource) на мережі залізниць. У такому випадку для визначення шляхів удосконалення системи ТО пристроїв ЗА також постає задача виявлення причиннонаслідкового зв' язку виникнення відмов.

У роботі [5] розглянуто теоретичні підходи до контролю, забезпечення та керування безпекою руху поїздів на залізничному транспорті і відповідно наслідки від порушень убезпечення та їх вплив на показники експлуатаційної роботи станцій. Також проведено аналіз виникнення транспортних подій та їх пристроїв ЗА можливі як небезпечні відмови, так і захисні. Отже, аналіз усього масиву відмов, що мають вплив на експлуатаційні показники, є актуальним. Слід зазначити, що у згаданій роботі наводяться дані, які опрацьовані протягом 2000-2009 рр.

\section{Визначення мети та завдання дослідження}

Аналіз статистичних даних з відмов пристроїв 3А та пошук кореляційного зв'язку між причинами виникнення відмов, відмовами та відповідно наслідками.

Для досягнення сформульованої мети потрібно вирішити такі завдання: опрацювання статистичних даних 3 відмов пристроїв ЗА; системно-структурний аналіз причин відмов; математичний розрахунок коефіцієнта кореляції; оцінка ступеня впливу організаційних заходів на результати ТО.

\section{Основна частина дослідження}

В основу аналізу покладені матеріали звітів [6] 3 експлуатаційної роботи галузі автоматики та телекомунікацій АТ «Укрзалізниця». На їх основі побудована узагальнююча табл. 1.

Таблиця 1

Статистичні дані з відмов пристроїв залізничної автоматики

\begin{tabular}{|c|c|c|c|c|c|c|c|c|}
\hline \multirow{3}{*}{ Рік } & \multirow{3}{*}{$\begin{array}{c}\text { Кількість відмов } \\
\text { пристроїв ЗА }\end{array}$} & \multicolumn{7}{|c|}{ Відмови пристроїв 3А, що віднесені за службою Ш } \\
\hline & & \multirow[t]{2}{*}{ кількість } & \multirow[t]{2}{*}{$\%$} & \multicolumn{2}{|c|}{$\begin{array}{c}3 \text { експлуатаційних } \\
\text { причин }\end{array}$} & \multicolumn{2}{|c|}{$\begin{array}{c}\text { які спричинили } \\
\text { затримку поїздів }\end{array}$} & \multirow{2}{*}{$\begin{array}{c}\text { кількість } \\
\text { затримок } \\
\text { поїздів }\end{array}$} \\
\hline & & & & кількість & $\%$ & кількість & $\%$ & \\
\hline 2010 & 6016 & 1432 & 23,8 & 1262 & 88,13 & 324 & 22,63 & 905 \\
\hline 2011 & 4837 & 1515 & 31,3 & 1337 & 88,25 & 298 & 19,67 & 863 \\
\hline 2012 & 4963 & 1552 & 31,3 & 1322 & 85,18 & 397 & 25,58 & 902 \\
\hline 2013 & 4144 & 1467 & 35,4 & 1197 & 81,6 & 409 & 27,88 & 884 \\
\hline 2014 & 4890 & 1196 & 24,5 & 968 & 80,94 & 302 & 25,25 & 720 \\
\hline 2015 & 4832 & 1299 & 26,9 & 1011 & 77,83 & 431 & 33,18 & 1038 \\
\hline 2016 & 4296 & 1241 & 28,9 & 969 & 78,08 & 472 & 38,03 & 1123 \\
\hline 2017 & 5310 & 1330 & 25,1 & 1135 & 85,34 & 674 & 50,68 & 1656 \\
\hline 2018 & 4954 & 1261 & 25,5 & 1065 & 84,46 & 664 & 62,34 & 1584 \\
\hline
\end{tabular}

Аналіз узагальнюючої таблиці вказує на те, що при існуючій організації системи ТО пристроїв ЗА спостерігається зниження кількості відмов, але “підтримуються" на одному рівні причини їх виникнення та зв'язок їх кількості 3 наслідками щодо затримки поїздів. Причому при зниженні загальної кількості відмов пристроїв ЗА і відповідно відмов пристроїв 3А, що віднесені за службою сигналізації та 
зв’язку (Ш), цей відсоток відмов зростає. Гіпотетично це можна пояснити різними темпами впровадження організаційно-технічних заходів зі зниження кількості відмов пристроїв ЗА у різних службах, що мають стосунок до роботи пристроїв 3А.

3 вини персоналу, що виконує ТО і ремонт пристроїв ЗА, відбувається від 77,83 до 88,25\% усіх відмов. Це свідчить про недостатню кваліфікацію, а часом і не відповідні, з точки зору ТО, особисті риси обслуговуючого персоналу, що впливає водночас і на стан пристроїв ЗА. Останнім часом суттєвий вплив має i недостатня кількість обслуговуючого персоналу. Помилки, які припускає персонал, найчастіше $\epsilon$ наслідком порушення технології виконання робіт, тобто недотримання вказівок нормативної та експлуатаційно-технічної документації $[7,8]$. Відсоток таких відмов міститься в межах від 46,3 до 59,5\%, що свідчить про стійкість негативних показників щодо особливостей обслуговуючого персоналу (табл. 2).

Причини відмов пристроїв залізничної автоматики

\begin{tabular}{|c|c|c|c|c|c|c|c|c|c|c|}
\hline \multirow{2}{*}{\multicolumn{2}{|c|}{ Причина відмови }} & \multicolumn{8}{|c|}{ Рік } & \multirow{2}{*}{$\begin{array}{c}\text { Середнє } \\
\text { значення }\end{array}$} \\
\hline & & 2010 & 2011 & 2012 & 2013 & 2014 & 2015 & 2016 & 2017 & \\
\hline \multirow{2}{*}{$\begin{array}{l}\text { Невиконання } \\
\text { робіт }\end{array}$} & кількість & 1 & 0 & 0 & 0 & 1 & 0 & 0 & 2 & 0,5 \\
\hline & $\%$ & 0,07 & 0 & 0 & 0 & 0,08 & 0 & 0 & 0,27 & 0,04 \\
\hline \multirow{2}{*}{$\begin{array}{c}\text { Порушення } \\
\text { технології } \\
\text { виконання робіт }\end{array}$} & кількість & 825 & 901 & 829 & 742 & 584 & 601 & 321 & 365 & 646 \\
\hline & $\%$ & 57,6 & 59,5 & 53,4 & 50,6 & 48,8 & 46,3 & 47,7 & 49,7 & 52,38 \\
\hline \multirow{2}{*}{$\begin{array}{c}\text { Порушення } \\
\text { термінів } \\
\text { заміни } \\
\end{array}$} & кількість & 1 & 0 & 1 & 3 & 0 & 1 & 2 & 0 & 1 \\
\hline & $\%$ & 0,07 & 0 & 0,06 & 0,2 & 0 & 0,08 & 0,3 & 0 & 0,08 \\
\hline \multirow{2}{*}{ Помилки РТД } & кількість & 46 & 49 & 73 & 80 & 57 & 50 & 30 & 20 & 50,6 \\
\hline & $\%$ & 3,21 & 3,2 & 4,7 & 5,45 & 4,77 & 3,85 & 4,46 & 2,72 & 4,11 \\
\hline \multirow{2}{*}{$\begin{array}{c}\text { Фізичне старіння } \\
\text { приладів }\end{array}$} & кількість & 278 & 277 & 285 & 274 & 242 & 263 & 170 & 209 & 249,8 \\
\hline & $\%$ & 19,4 & 18,5 & 18,4 & 18,7 & 20,2 & 20,3 & 25,3 & 28,5 & 20,25 \\
\hline \multirow{2}{*}{$\begin{array}{c}\text { Схемний } \\
\text { недолік }\end{array}$} & кількість & 6 & 5 & 22 & 16 & 13 & 4 & 2 & 5 & 9,125 \\
\hline & $\%$ & 0,4 & 0,3 & 1,42 & 1,09 & 1,09 & 0,31 & 0,3 & 0,68 & 0,74 \\
\hline \multirow{2}{*}{$\begin{array}{c}\text { Невідомі } \\
\text { експлуатаційні } \\
\text { причини }\end{array}$} & кількість & 105 & 105 & 112 & 83 & 71 & 92 & 36 & 62 & 83,25 \\
\hline & $\%$ & 7,3 & 6,93 & 7,22 & 5,66 & 5,94 & 7,08 & 5,35 & 8,45 & 6,75 \\
\hline \multirow{2}{*}{ Інші причини } & кількість & 170 & 178 & 230 & 269 & 228 & 288 & 112 & 69 & 193 \\
\hline & $\%$ & 11,8 & 11,8 & 14,8 & 18,3 & 19,1 & 22,2 & 16,6 & 940 & 15,65 \\
\hline
\end{tabular}

Порушення технологічної дисципліни можуть бути зумовлені не тільки низькою кваліфікацією персоналу, але й цілою низкою інших причин [9], а саме:

a) недоліками системи підвищення кваліфікації;

б) низьким рівнем або відсутністю заходів із соціального розвитку людини та колективу, що в сучасній інтерпретації у менеджменті ідентифікується як team building;

в) слабкою виховною роботою;

г) незадовільною роботою 3 управління якістю праці;

д) скороченням фондів матеріального заохочення;

е) особистими якостями обслуговуючого персоналу, зокрема низькою кваліфікацією, яка у свою чергу призводить до:

- пропуска дефектів; неузгодженості;
- виконання непотрібних дій, а пропуска потрібних;

- порушення норм;

- неправильного вмикання;

- невідповідного зчитування даних 3 вимірювальних приладів;

- хибного напрямку пошуку;

- неповної перевірки;

- хибного бракування;

є) недостатньою виробничою та соціальною дисципліною, що у свою чергу виявляється у зниженні якості внаслідок слабкого контролю та відсутності внутрішньої мотивації персоналу;

ж) навмисним форсуванням режиму, що пов'язано iз затримками ремонтних робіт, відмовами та 
порушенням термінів постачання приладів, матеріалів, інструментів.

Поява тих чи інших відмов по-різному впливає на виконання основної задачі дистанції сигналізації та зв'язку та іiі основних складових. Отже, важливим є встановлення наявності чи відсутності кореляційного зв'язку між відмовами та кількістю затримок поїздів (табл. 1). Пошук кореляційного зв'язку виконано відповідно до рекомендацій [10-12].

Для значень кількості відмов (індекс $B$ ), що спричинили затримку поїздів, і кількості затримок (індекс 3), що розглядаються як випадкові величини, знаходимо статистичні середні - $\tilde{m}$. Незміщені оцінки для дисперсії та середнього квадратичного відхилення знаходимо відповідно за формулами:

$\tilde{D}_{B}=\frac{1}{n-1} \sum_{i=1}^{n}\left(B_{i}-\tilde{m}_{B}\right)^{2}, \tilde{\sigma}_{B}=\sqrt{\tilde{D}_{B}} ;$

$\tilde{D}_{3}=\frac{1}{n-1} \sum_{i=1}^{n}\left(3_{i}-\tilde{m}_{3}\right)^{2}, \tilde{\sigma}_{3}=\sqrt{\tilde{D}_{3}}$.

де $n$-кількість реалізацій випадкових величин.

Для знайдених значень знаходимо оцінку для коваріації [11]:

$$
\tilde{K}_{B 3}=\left[\frac{1}{n} \times \sum_{i=1}^{n}\left(B_{i} \times 3_{i}-\tilde{m}_{B} \times \tilde{m}_{3}\right)\right] \times \frac{n}{n-1},
$$

звідки отримуємо оцінку для коефіцієнта кореляції [11]:

$$
\tilde{r}_{B 3}=\frac{\tilde{K}_{B 3}}{\sqrt{\tilde{D}_{B} \times \tilde{D}_{3}}}
$$$$
P_{\text {зБВР }}=\left(1-\left(1-P_{\text {БвРП }}\right) \cdot\left(1-P_{\text {ВГр }} \cdot\left[1-\left(1-P_{\text {д }}\right) \cdot\left(1-P_{\text {КД }}\right)\right] \cdot P_{\text {ЯВ }} \cdot P_{\text {ПтО }}\right)\right) \cdot P_{\text {БВРР }}
$$

де $P_{\text {зБвр }}$ - загальна імовірність безвідмовної роботи;

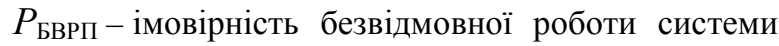
за поступовими відмовами;

$P_{\text {БврР }}$ - імовірність безвідмовної роботи системи за раптовими відмовами;

$P_{\text {Пто }}$ - імовірність помилок при виконанні ТО;

$P_{\text {ВГр }}-$ імовірність виконання графіка ТО;

$P_{\text {д }}$ - імовірність діагностування;

$P_{\text {яв }}-$ імовірність якісного виконання відновлювальних робіт;

$P_{\text {Кд }}$ - імовірність контролю діагностування ТО.
Отриманий коефіцієнт кореляції становить 0,96 . Це свідчить про те, що між випадковими величинами, які досліджувалися, існує досить щільна кореляційна залежність позитивного, 3 точки зору математики, характеру: при збільшенні кількості відмов збільшується i кількість затримок. Також можна спостерігати і те, що відсоток відмов, які спричинили затримку поїздів, рахуючи від загальної кількості відмов, зростає. Отже, технологія обслуговування пристроїв 3А істотно впливає на якість послуг, що надає залізничний транспорт у цілому.

Класифікація причин відмов дає певне уявлення про структуру та фрагментацію суб'єктивного фактора обслуговуючого персоналу та відповідні кількісні показники (табл. 2). Для більш детального аналізу потрібно додатково мати дані про освіту, склад та рівень його компетентностей.

Відповідно до статистичних даних (табл. 2), найбільша частина відмов відбувається через порушення технології виконання робіт, тобто через помилки обслуговуючого персоналу. Помилки обслуговуючого персоналу згруповані залежно від їх впливу на хід ТО. Для пристроїв ЗА можлива поява як відмов раптового, так і поступового характеру 3

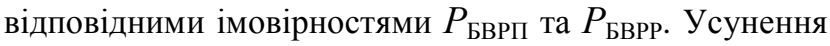
раптових відмов можна досягти шляхом упровадження високонадійних систем та деякими організаційними заходами. Як відомо, запобігання поступовим відмовам (процес накопичення несправностей) можливе за рахунок проведення ТО відповідно до графіка 3 імовірністю його виконання. При безпосередньому виконанні робіт ТО мають вплив показники, що характеризують якісне виконання заходів 3 діагностування та відновлення. Залежно від впливу помилок на хід ТО можна скласти розрахункову схему (рис. 1), що представлена таким виразом:

\section{$\left.\left.\cdot P_{\text {яв }} \cdot P_{\text {Пто }}\right)\right) \cdot P_{\text {БврР }}$}

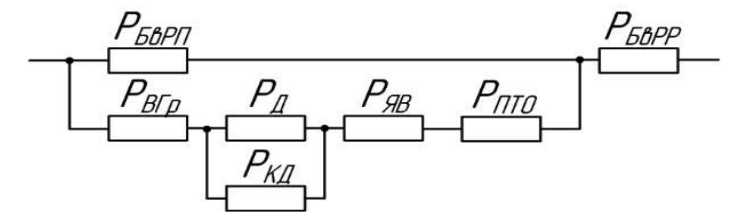

Рис. 1. Розрахунково-логічна схема безвідмовності роботи пристроїв $3 \mathrm{~A}$

Для пристроїв електричної централізації (ЕЦ) більшість імовірностей не відомі. Однак для оцінки впливу імовірності контролю за виконанням ТО можна скористатися даними, отриманими для авіаційного транспорту [13]: $\quad P_{\text {Пто }}=0,62-0,54 ; \quad P_{\text {д }}=0,75-0,71$; 
$P_{\text {Яв }}=0,72-0,66$. Для пристроїв ЕЦ $P_{\text {БвРП усереднено }}$ приймається $0,926, P_{\text {БврР }}-0,968[3,4]$.

Для оцінки ступеня впливу контролю за ходом виконання ТО було проаналізовано лінійні функції $P_{\text {зБвР }}=f\left(P_{\text {Кд}}\right)$ для різних значень імовірності виконання графіка ТО. Як видно $з$ графіків (рис. 2), підвищення рівня роботи пристроїв можливе за рахунок контролю за виконанням графіка ТО та дотриманням технології, які можна здійснювати як організаційними заходами, шляхом раптових перевірок керівництвом та ревізорами, так і за допомогою спеціалізованих апаратнопрограмних комплексів (АПК), 3 аналізом динаміки роботи пристроїв та відповідних часових параметрів у процесі роботи пристроїв ЗА при виконанні ТО.

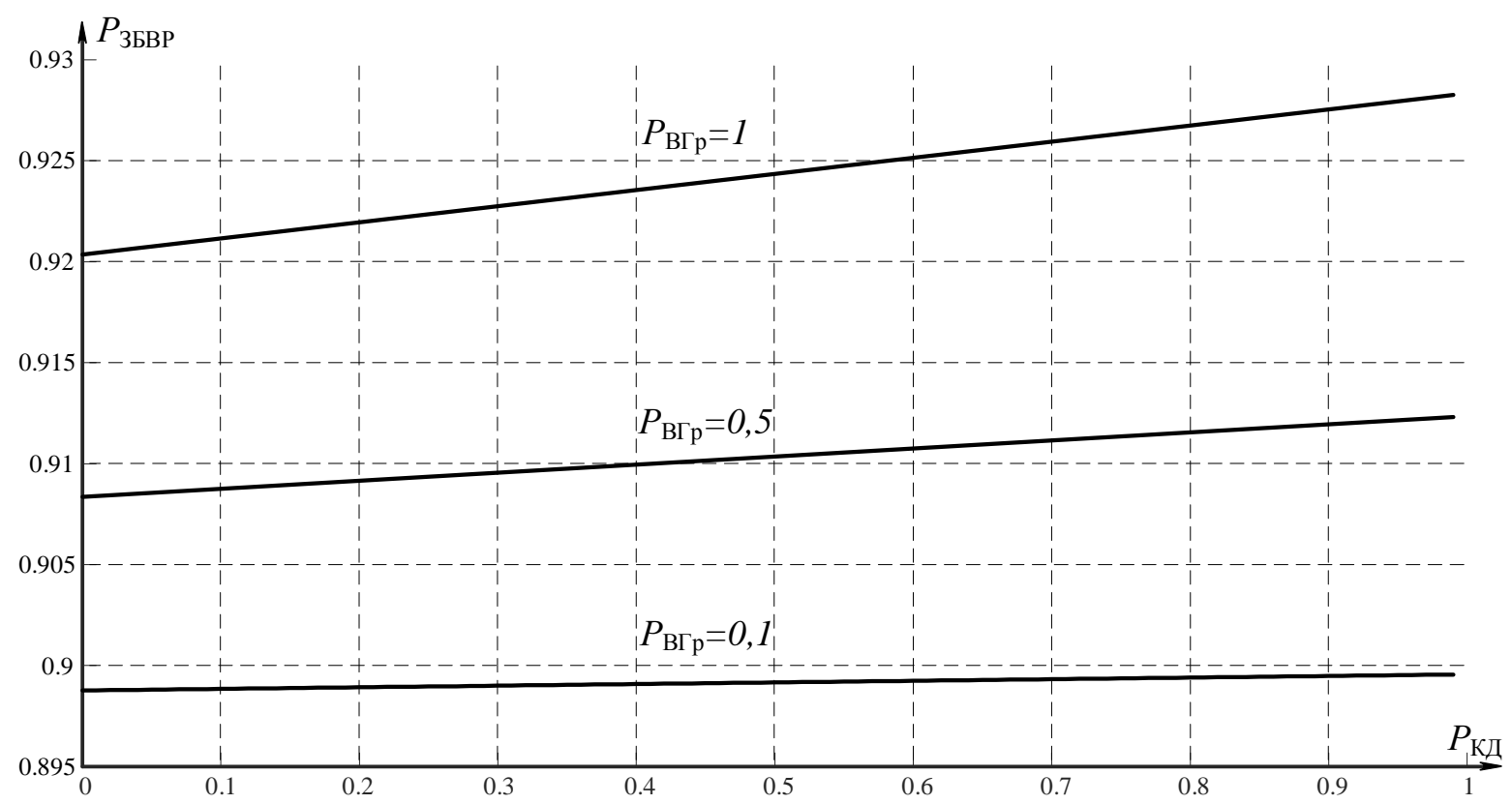

Рис. 2. Оцінка ступеня впливу технічного контролю на результати ТО

При використанні АПК для контролю виконання процесу ТО велику увагу необхідно приділяти способу отримання інформації. У загальному випадку етапи отримання достовірної інформації від контрольованого об'єкта можливо поділити на 3 основні групи (рис. 3).

Таким чином, велику увагу слід приділити правильному вибору параметрів діагностування та відповідних граничних меж (як верхніх, так і нижніх) 3 урахуванням середніх значень, що очікуються, та дисперсії. Також необхідно правильно обрати методи оцінки отриманої інформації [14], що допоможуть суттєво підвищити значення правильного виконання ТО за рахунок статистичної обробки отриманих даних.

Окрему увагу слід приділити обслуговуванню пристроїв, що мають поступові відмови. До таких можна віднести: кабельні лінії, рейкові кола, світлодіодні матриці світлофорів. Під час обслуговування цих пристроїв необхідно велику увагу приділяти обробці отриманих даних, оскільки при наявності великої кількості достатньо достовірних вимірювань можливо передбачити час настання відмови 3 досить високою точністю, використовуючи оптимальні алгоритми оцінювання $[4,14,15]$.
Окремо слід звернути увагу на таку причину відмов, як фізичне старіння приладів (табл. 2). Станом на теперішній час на мережі залізниць України експлуатується достатньо велика кількість пристроїв, що працюють понаднормативний термін (табл. 3).

Зазначену проблему можна вирішити за допомогою інтенсифікації впровадження мікроелектронних технічних засобів 3А на магістральному залізничному транспорті. 


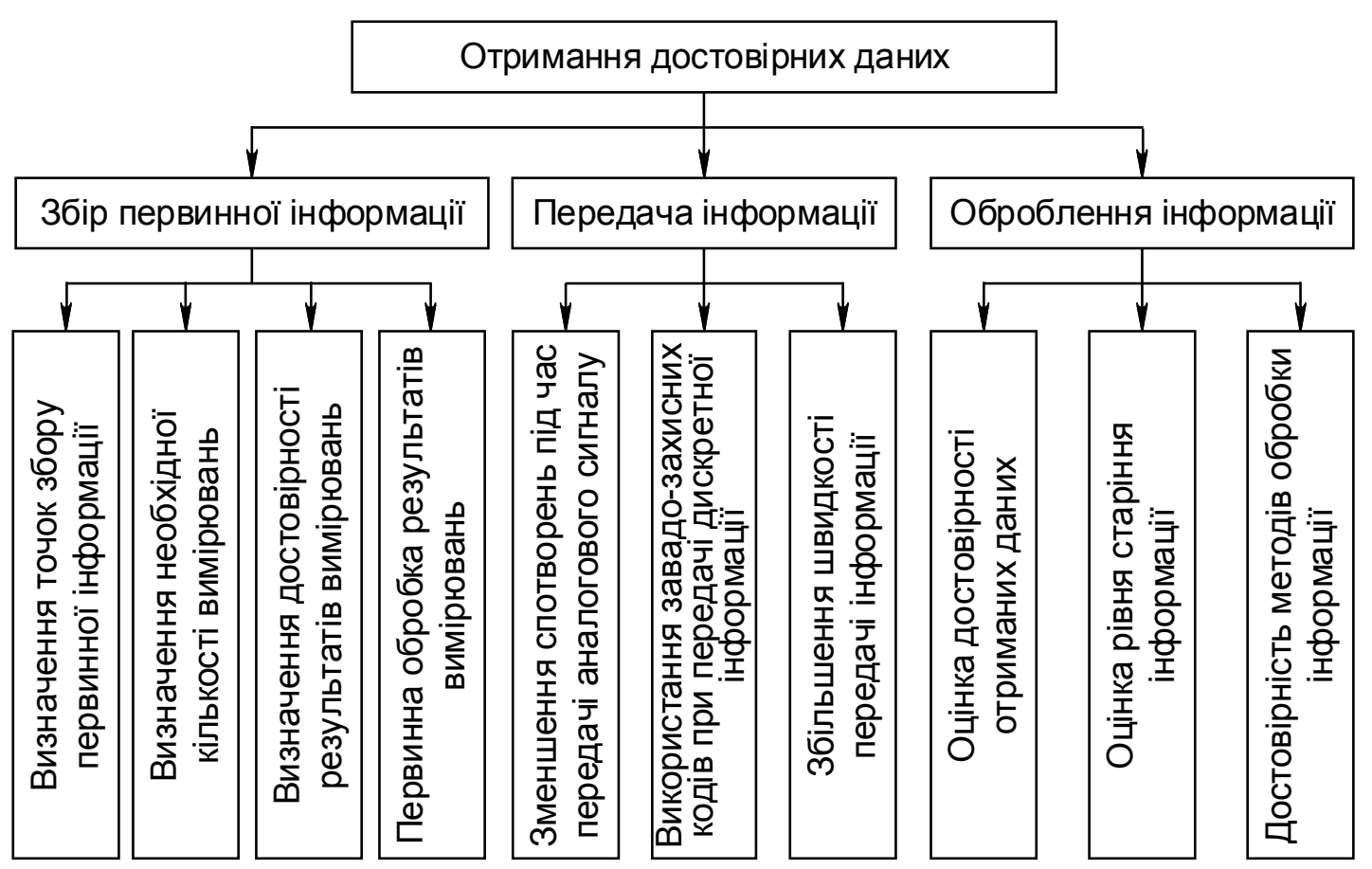

Рис. 3. Складові отримання інформації про об’єкти технічного контролю

Таблиця 3

Знос основних технічних засобів

\begin{tabular}{|l|c|c|c|c|}
\hline \multirow{2}{*}{\multicolumn{1}{c|}{ Система, вимірювач }} & \multicolumn{2}{c|}{$\begin{array}{c}\text { Працює в межах } \\
\text { нормативного терміну }\end{array}$} & \multicolumn{2}{c|}{$\begin{array}{c}\text { Працює понад } \\
\text { нормативний термін }\end{array}$} \\
\cline { 2 - 5 } & кількість & $\%$ & кількість & $\%$ \\
\hline Електрична централізація, стрілки & 5233 & 17 & 26095 & 83 \\
\hline Автоблокування, км & 2722,5 & 22 & 9522,7 & 78 \\
\hline Напівавтоматичне блокування, км & 2543 & 37 & 4292 & 63 \\
\hline Диспетчерська централізація, км. & 1709,6 & 38 & 2819,1 & 62 \\
\hline Гіркові пристрої, стрілки & 277 & 41 & 395 & 59 \\
\hline Гіркові пристрої, уповільнювачі & 89 & 8 & 1063 & 92 \\
\hline Загалом, технічні одиниці & 11453 & 35,4 & 20891 & 64,6 \\
\hline
\end{tabular}

\section{Висновки}

Відомо, що при планово-профілактичній стратегії ТО велике значення має кваліфіковане виконання в повному обсязі графіка робіт 3 ТО. Отримані дані свідчать про те, що на практиці це не завжди здійснюється. Отже, при безперечно існуючих у планово-профілактичній стратегії позитивних моментах виникають передумови до іiі зміни або удосконалення.

Зважаючи на те, що впровадження перспективних систем та пристроїв ЗА не набуло високих темпів, існуючі пристрої та системи можуть експлуатуватися ще досить значний термін, тобто проблеми, висвітлені в роботі, $є$ актуальними і потребують вирішення.

Для вдосконалення існуючої системи ТО пристроїв 3А, а отже, і підвищення надійності, треба зменшити вплив обслуговуючого персоналу на надійність системи "людина-техніка", тобто необхідно максимально виключити його можливі втручання в роботу пристроїв. Цього можна досягти заходами різного характеру, а саме:

автоматизацією контролю стану пристроїв 3А та їх параметрів, що має сприяти завчасному запобіганню відмовам при наявності поступової зміни параметрів;

організаційно-технічними заходами зі збільшення спільної взаємодії працівників служб, що мають стосунок до роботи пристроїв 3А;

зміною принципів організації роботи підрозділів 3 підготовки виробництва дистанції сигналізації та зв’язку, що призведе до збільшення централізації ТО бригадами відповідальних та найбільш кваліфікованих працівників;

оптимальною обробкою результатів вимірювань контрольних параметрів за допомогою 
мікропроцесорних засобів з використанням сучасного математичного апарату обробки та моделювання;

раціоналізацією процесів обслуговування пристроїв, що мають поступову відмову;

упровадженням нових систем 3 низьким рівнем потреби в ТО або наявністю вбудованого діагностування.

\section{Список використаних джерел}

1. Талалаев В.И. Анализ работы устройств СЦБ. Автоматика телемеханика и связь. 1993. №8. C. 2-7.

2. Moiseenko V., Kameniev O., Gaievskyi V. Predicting a technical condition of railway automation hardware under conditions of limited statistical data. EasternEuropean Journal of Enterprise Technologies. 2017. №3/9(87). P. 26-35. ISSN 1729-3774.

3. Kameniev O., Lapko A., Shcheblykina E. Improvement of technologies for the development of modern rail automation systems. Machines. Technologies. Materials: International Scientific Journal. 2017. Vol. 11, Iss. 11. P. 541-544.

4. Лапко А. О. Удосконалення технічного обслуговування пристроїв електричної сигналізації та централізації шляхом комплексного контролю технічного стану : автореф. дис... канд. техн. наук : 05.22.20. Харків, 2010. 20 с.

5. Самсонкін В. М., Мойсеєнко В. І. Теорія безпеки на залізничному транспорті: монографія. Київ: Каравела, 2014. 248 с.

6. Аналіз експлуатаційної роботи галузі автоматики, телемеханіки та зв'язку Укрзалізниці за 20102018 pp. Київ: Департамент автоматики та телекомунікацій АТ «Укрзалізниця».

7. Інструкція з технічного обслуговування пристроїв сигналізації, централізації та блокування (СЦБ). Київ: НВП Поліграфсервіс, 2009. 111 с.

8. Пристрої сигналізації, централізації та блокування. Технологія обслуговування. Київ: САМ, 2006. $461 \mathrm{c}$.

9. Стрелков Ю. К. Инженерная и профессиональная психология: учеб. пособие. Москва: Академия; Высш. шк., 2001. 360 с.

10. Li T., Li Yu., Zhao H. The method for fault risk assessment of distribution equipment. China International Conference on Electricity Distribution. 2014. P. 517-521.

11. Boinik A., Prohonnyi O., Kameniev O., Lapko A., Kuzmenko D., Shcheblykina O. Development and investigation of methods of graphic-functional modeling of distributed systems. Eastern-European Journal of Enterprise Technologie. 2018. P. 59-69.

12. Вентцель Е. С., Овчаров Л. А. Теория вероятности и её инженерное приложение. Москва: Высш. шк., 2000. $480 \mathrm{c}$.
13. Ханан Я. Оптимізація процесів технічного обслуговування повітряних суден : автореф. дис... канд. техн. наук : 05.22.20. Київ, 1999. 20 c.

14. Minieka E. Optimization Algorithms for Networks and Graphs. Second Edition. New York: Marcel Dekker, Inc., 1978. 356 p.

15. Сейдж Э. П., Уайт Ч. С. Оптимальное управление системами. Москва: Радио и связь, 1982. 392 с.

\section{A. Lapko, O. Kameniev, V. Sahaidachnyi, T. Kotsiuba. Operational indicators of work of devices of railway automation.}

Abstract. In order to maintain the regularity of the devices of railway automation, the planned preventive maintenance strategy for the organization of the maintenance system itself is used at the present time. The disadvantage of the mentioned strategy is a significant dependence of the probability of failure of the devices on the quality and timeliness of the performance of the technological processes of maintenance. Any deviation during the performance of the standard maintenance conditions is reduced to the delay in the movement of trains on the site. Analysis of statistical data indicates at the same time an explicit causal link of the total delay time with the operation of the profile signaling and communication service of the railway. In order to analyze the influence of the maintenance process on the probability of fail-safe operation of the railway automation devices, and, accordingly, the influence on the parameters of the transportation process, the statistical data on failures of the devices of the railway automatics are analyzed. As a result, a correlation between the number of failures and the number of train delays was obtained. At the same time, the settlement-logic scheme of reliability was formed as a function of several components of maintenance as arguments. These components are indicators of the quality of maintenance of automation systems, which take into account temporary, ergative and other parameters of production processes.

The established correlation dependencies allow us to use the method of statistical forecasting in relation to the outdated relay-contact systems of automation, as well as to more modern microelectronic programmable technical means. For them, a completely different approach to technical diagnosis and maintenance is acceptable, which is due to the multi-channel, high diagnostic and maintainability. Implementation of this methodology will allow us to apply better technical maintenance strategies in the future.

Keywords: maintenance, failure, correlation, technical control, diagnostics.

Надійшла 30.05.2019p. 
Лапко Антон олександрович, канд. техн. наук, доцент кафедри автоматики та комп'ютерного телекерування рухом поїздів Украӥнського державного університету залізничного транспорту, Харків, Украӥна. E-mail: a.o.lapko@kart.edu.ua. ORCID ID: 0000-0003-2881-1238

Каменев Олександр Юрійович, канд. техн. наук, доцент кафедри автоматики та комп'ютерного телекерування рухом поїздів Украӥнського державного університету залізничного транспорту, Харків, Україна. ORCID ID: 0000-0001-5372-5628 E-mail: alexstein@kart.edu.ua.

Сагайдачний Владислав Геннадійович, аспірант кафедри автоматики та комп'ютерного телекерування рухом поїздів Українського державного університету залізничного транспорту, Харків, Украӥна. ORCID ID: 0000-0003-2511-9852 E-mail: v.sahaidachnyi@kart.edu.ua.

Коцюба Тетяна Анатоліївна, завідувач відділення "Монтаж, обслуговування та ремонт автоматизованих систем керування рухом на залізничному транспорті", "Технічне обслуговування та ремонт пристроїв електропостачання залізниць” Харківського коледжу транспортних технологій, Украӥна. ORCID ID: 0000-0003-2554-2714 E-mail: kotsubata@ukr.net

Lapko Anton Oleksandrovich, Ph.D., associate professor Department of automatic and computer remove control of train traffic on Ukrainian State University of Railway Transport, Kharkiv, Ukraine. ORCID ID: 0000-00032881-1238 E-mail: a.o.lapko@kart.edu.ua.

Kameniev Oleksandr Yurevich, Ph.D., associate professor Department of automatic and computer remove control of train traffic on Ukrainian State University of Railway Transport, Kharkiv, Ukraine. ORCID ID: 0000-00015372-5628 E-mail: alexstein@kart.edu.ua.

Sahaidachnyi Vladyslav Hennadiiovych, postgraduate Department of automatic and computer remove control of train traffic on Ukrainian State University of Railway Transport, Kharkiv, Ukraine. ORCID ID: 0000-00032511-9852 E-mail: v.sahaidachnyi@kart.edu.ua.

Kotsiuba Tetiana Anatolyevna, head of the department "Installation, maintenance and repair of automated railway traffic control systems", "Maintenance and repair of railway power supply devices" of the Kharkov College of Transport Technologies, Ukraine. ORCID ID: 00000003-2554-2714 E-mail: kotsubata@ukr.net 